\title{
Identification of specimen labeling errors in pathology specimens received from different wards of the hospital: A patient safety approach
}

\author{
Seyed Saeed Tabatabaee ${ }^{1}$, Saeideh moosavi ${ }^{2}$, Soheyla Gholami ${ }^{3}$, Shoayb Rafiei ${ }^{4}$, Azam Molapour ${ }^{5}$, \\ Rohollah Kalhor $^{6}$ \\ 1. Assistant Professor, Social Determinants of Health Research Center, Mashhad University of Medical Sciences, Mashhad, \\ Iran. ORCID ID: 0000-0001-5758-0681 \\ 2. B.Sc. in Occupational Health, School of Public Health, Qazvin University of Medical Sciences, Qazvin, Iran. ORCID ID: \\ 0000-0001-6240-907X \\ 3. M.Sc. of Health Services Management, Dezful University of Medical Sciences, Dezful, Iran. ORCID ID: 0000-0002-1759- \\ 9182 \\ 4. M.Sc in Health Services Management, School of Public Health, Qazvin University of Medical Sciences, Qazvin, Iran. \\ ORCID ID: 0000-0001-8897-4392 \\ 5. M.Sc in Microbiology, Qazvin University of Medical Sciences, Qazvin, Iran. ORCID ID: 0000-0002-5718-2920 \\ 6. Associate Professor, Social Determinants of Health Research Center, Research Institute for Prevention of Non- \\ Communicable Diseases, Qazvin University of Medical Sciences, Qazvin, Iran., (Corresponding Author), Tel: +98- \\ 2833369581, Email: R.kalhor@gmail.com, ORCID ID: 0000-0002-6146-8761
}

\begin{abstract}
Background and Aim: Nowadays, patient safety culture is recognized as an important issue in providing high quality services for the patients around the world. Unsafe care and services can lead to mortality, disability, prolonged hospitalization and increased costs of treatment. Therefore, the present study aimed to identify the errors associated with the labels of pathology samples in Qazvin hospitals.

Materials and Methods: This descriptive-analytic study was performed on the basis of a census sampling and included samples obtained from the operating rooms of five educational hospitals in Qazvin University of Medical Sciences in 2018. A standard checklist was used to collect information. Our professors and pathologists determined validity and reliability of the checklist by Cronbach's alpha of 0.89 . Using SPSS 21 the results were analyzed by statistical indices.
\end{abstract}

Results: Among 1164 biopsy samples, 6425 errors were detected. The highest error rates were related to lack of registration of the patient's age (564 cases; 48.4\%), lack of registration of the name of the of the patients' fathers (562 cases; 48.2\%), and lack of recording the number of biopsies $(558 ; 47.9 \%)$ and the lowest rates of errors included empty container $(10$ cases; $0.86 \%$ ), lack of recording the number of specimens (14 cases; $1.2 \%)$ and lack of using appropriate fixative $(16 ; 1.37 \%)$ respectively.

Conclusion: Regarding the frequency of labeling errors in the pre-analytical phase in the pathology ward, use of bar code imprinted in the sample containers, lack of using paper applications, use of radio frequency chip technology, use of a re-checking system and improvement of communication in the operating rooms can result in reducing these errors.

Keywords: Patient safety, Labeling errors, Pathology specimens

Received: May 21, $2019 \quad$ Accepted: Feb 2, 2020

How to cite the article: Seyed Saeed Tabatabaee, Saeideh moosavi, Soheyla Gholami, Shoayb Rafiei, Azam

Molapour, Rohollah Kalhor. The Identification of Specimen Labeling Errors in Surgical Pathology Deliverded from Different Parts of the Hospital: Patient Safety Approach.SJKU 2020;25(4):70-78.

Copyright (C) 2018 the Author (s). Published by Kurdistan University of Medical Sciences. This is an open access article distributed under the terms of the Creative Commons Attribution-Non Commercial License 4.0 (CCBYNC), where it is permissible to download, share, remix, transform, and buildup the work provided it is properly cited. The work cannot be used commercially without permission from the journal 


\section{شناسايى خطاهاى مرتبط با بر خسب تذارى نمونهاى باتولوزى جراحى ارسال شده از بخشهاى مختلف بيمار ستان: رويكرد ايمنى بيمار}

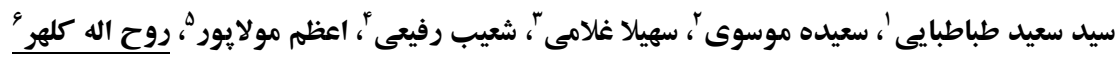

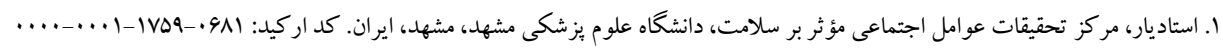

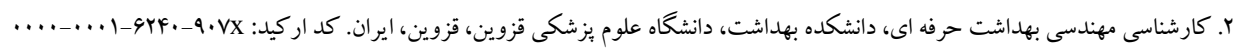

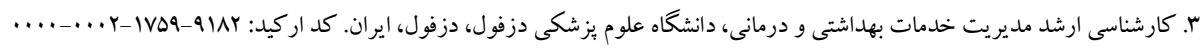

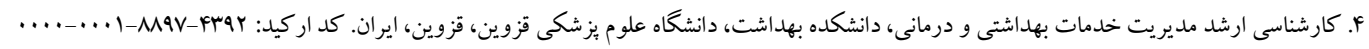

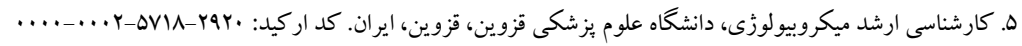

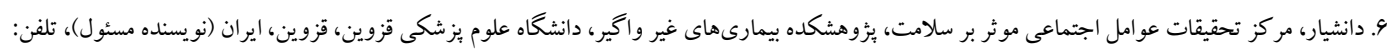

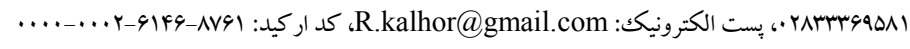

جكيده زمينه و هدف: امروزه فرهنگ ايمنى بيمار به عنوان يكك عنصر مهم در ارائه خدمات با كيفيت به بيماران در سراسر جهان شناخته شده است. مر اقبت و خدمات غير ايمن مىتواند منجر به مرگك و مير، ناتوانى، افزايش طول مدت بسترى و افزايش هزينههاى درمان

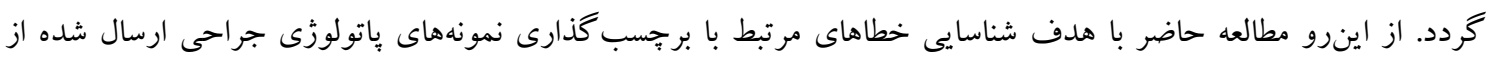

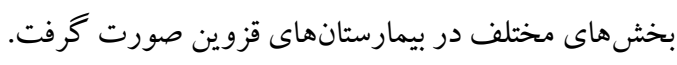
مواد و روش ها: مطالعه حاضر يك ئزوهش توصيفى تحليلى است كه به صورت مقطعى در سال IT I در اتاق عمل ه بيمارستان آموزشى دانشگاه علوم بزشكى قزوين كه به صورت سرشمارى وارد مطالعه شدند انجام شد. جهت جمع آورى اطلاعات از

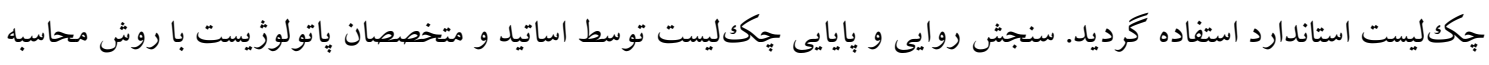
آلفاى كرونباخ وه/ • صورت كرفت. نتايج با استفاده از شاخصهاى آمارى و نرمافزار SPSS نسخه اY و آمار توصيفى مورد تجزيه و تحليل قرار كرفت.

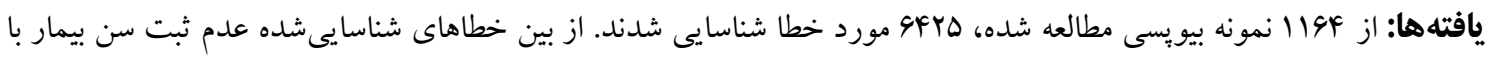

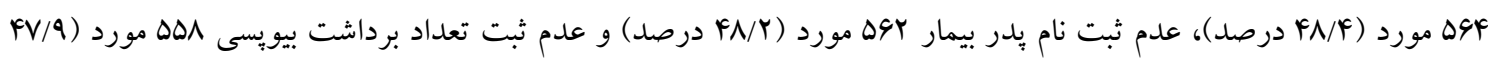

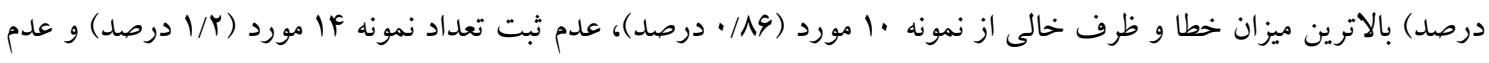
استفاده از تثبيت كننده مناسب 19 مورد (T// ادرصد) به ترتيب يايينترين ميزان خطاها را به خود اختصاص دادند. نتيجه Fيرى: با توجه به فراوانى خطاهاى برجسب گذارى در مرحله قبل از تجزيه و تحليل در بخش پِاتولوزى، استفاده از فناورى بار كد در ظرفهاى نمونه، حذف فرم درخواست كاغذى انجام باتولوزى، استفاده از تكنولوزى تراشه فر كانس راديويى، استفاده از سيستم جّك مجدد و بهبود ارتباطات در اتاقهاى عمل مى تواند ميزان در جهت كاهش اين خطاها موثر باشد.

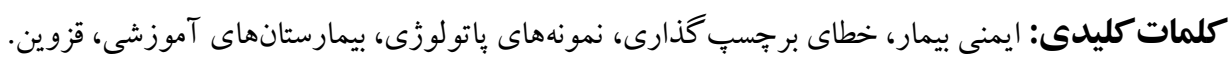
وصول مقاله: اس/T/T اصلاحيه نهايى: 
شناسى از قبيل خطاهاى Labeling يا برجسب نامناسب توجه شده است(^). خطاهاى برجّب نامناسب مىتواند منجر به درمانهاى نامناسب و يا منع درمان در بيماران با سرطانهاى ناشناخته شود. شناسايى اينگً نه خطاها ممكن است از طريق شناسايى نادرست يكك بيمار و يا نمونه بيمار يا محل نمونه بردارى باشد جنين خطاهاى ممكن است منجر به آسيبهاى جدى براى بيمار شود(9). اين خطاها در دو طبقه قرار مى گيرند؛ يكى مربوط به خطاهاى حاصل از عدم شناسايى دقيق بيماران و ديخرى به خاطر عدم شناسايى دقيق نمونه. در خطاى نوع اول يكك نمونه با برجسب به بخش آسيب شناسايى ارسال مى گردد كه نام بيمار برروى آن نادرست ثبت شده است در نوع ديخر نام بيمار درست ثبت شده است اما محل نمونه بردارى و يا زمان نمونه بردارى و ... اشتباه ثبت شده است. مطالعات متعددى ميزان اين خطاها را در نمونههاى ارسالى با آزمايشگاه گزارش نمودداند(11•). از جمله در مطالعهاى كه بثزوهشخران به بررسى ميزان بروز و انواع خطاهاى مربوط به نمونههاى جراحى در بيماران جراحى شده يرداختند يافتهاى مطالعه نشان مىدهد كه به

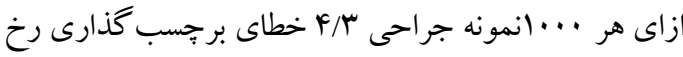
مىدهد(Y) I). در مطالعه ديخرى كه به بررسى خطاهاى

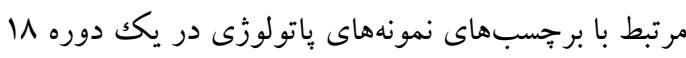
ماهد برداختند VD خطا شناسايى شد كه از اين تعداد هذه خطا(س/\%) مرتبط با نام بيمار و \| خطا(FF/\%) مرتبط با مكان نمونه بود. اكثر خطاهاى مرتبط به برجسبهاى نمونهاى آسيبشناسى در اتاق نخهدارى نمونهها جايى كه نمونهها از آنجا به آزمايشگاههاى آسيب شناسى ارسال مىشود اتفاق مى افتاد؛ در نهايت اين مطالعه به اين نتيجه رسيد كه استفاده از فن آورىهاى جديد مانند باركد مى تواند از بروز

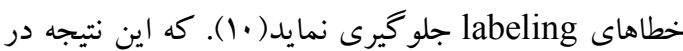
مطالعات ديكرى نيز به اثبات رسيد(f|r-س|). بطوريكه نتايج مطالعهاى صورت كرفته در اين زمينه نشان داد كه با اجراى سيستم بار كد طى يكك سال تقريبا از بروز ^• • خطاى مربوط

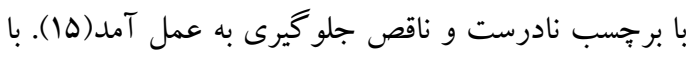

مقدمه

Institute of ) IOM به دنبال گزارش موسسه يزشكى (Medicine تحت عنوان (اسازمانهاى مراقبتهاى بهداشتى بايد فرهنگ ايمنى را توسعه دهند تا فر آيندهاى مراقبت و نيروى كار سازمان بر بهبود قابليت اطمينان و ايمنى مراقبت از بيماران متمركز شوند) كه نقطه عطفى در برجسته نمودن اهميت فرهنگ ايمنى در سازمانهاى بهداشتى درمانى بود( (1). فرهنگ ايمنى به طور فزايندهاى به عنوان يكك عنصر مهم در ارائه مراقبت با كيفيت از بيمار شناخته شد. و ايمنى بيمار براى ارتقاء كيفيت مراقبتهاى بهداشتى به يكى از يارامترهاى مهم نظارت بر تمام سازمانهاى مراقبتهاى بهداشتى درمانى در سراسر جهان تبديل شد(Y). فرهنگ ايمنى مىتواند به عنوان نخرشها، باورها، ادراككها و و ارزشهاى افراد در يكك محل كار تعريف شود. اين شامل مهارتهاى غير فنى مانند كار گروهى، ارتباطات و گزارش رويدادها مىباشد. نقص در اين جنبههاى مراقبت به اندازه اشتباهات فنى و يا كاستىها مىتواند به بيماران آسيب برساند(r). عدم موفقيت در ارتباطات يكى از عوامل مهم و اصلى در انواع رويدادهاى ناكوار است(F). شكست در ارتباطات به طور ويزه در بين اعضاء كادر جراحى مساله ساز هستند كه منجر به مرگك و مير، ناتوانى، افزايش طول مدت بسترى و افزايش هزينهاى درمان مى گردد(4-ه) در مطالعات مربوط به بيمار ان جراحى شده، ناتوانى در برقرارى ارتباط به عنوان علت ريشه ايى در •^ درصد رويدادهاى ناگوار، VV درصد اعمال جراحى در محل اشتباه و ديگر خطاهاى يزشكى در اتاق عمل شناسايى شدهاند(^-V).يك نمونه از عدم موفقيت در برقرارى ارتباطات كه براى بيماران خطرات زيادى را مطرح مى كند، Labeling errors يا عدم برجسب مناسب مربوط به مشخصات بيمار و نمونه جراحى بيش از ارسال آن به آزمايشگاه ياتولوزى است. به طور ويزٔه يكك خطا در ارتباطات زبانى و تفسير آن خطر عدم برجّب نمونههاى ياتولوزى را افزايش مى دهد(V). با اين حال در بررسىهاى اخير كمتر به خطاهاى موجود در بخش آسيب 
اطلاق مى گردد، خطا در سمت و جهت نادرست؛ كه مربوط به نمونهاى زوجى مثل جشم و گوش مىباشد و خطاهاى مربوط به محل نمونه كه شامل محل بافت مىباشد كه شامل بستان، بوست و ... مىباشد.

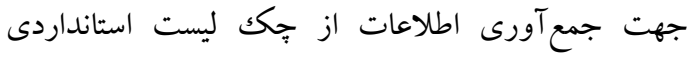
كه Makary و همكاران (Y... كرفته بود استفاده شد(Y)). براى سنجش روايى جگككليست

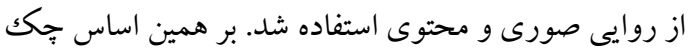

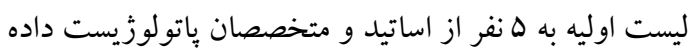
شد كه در نهايت بر روى جككليست اتفاق نظر حاصل

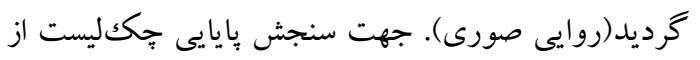

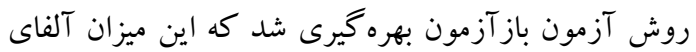

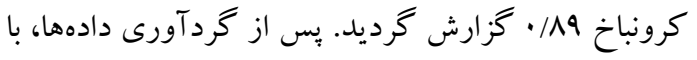

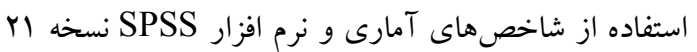

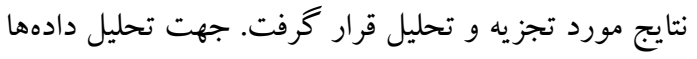

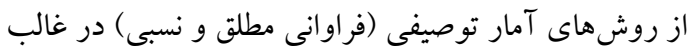

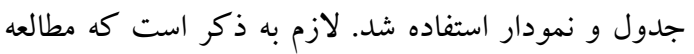

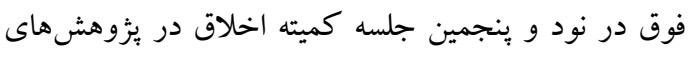

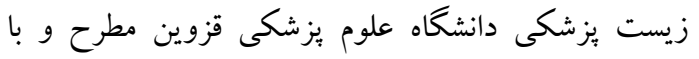
دريافت كد IR.QUMS.REC.1395.10 مورد تاييد قرار

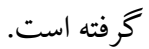

يافته ها از llak نمونه بيويسى مطالعه شده، GFrb مورد خطا شناسايى شدند. از بين خطاهاى شناسايى شده عدم ثبت سن لـ

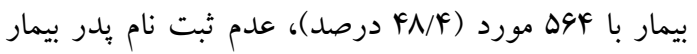

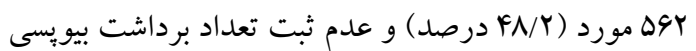

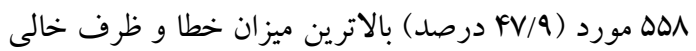

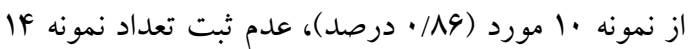
مورد (ب/ ا درصد) و عدم استفاده از تثبيت كننده مناسب 19

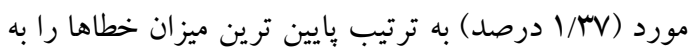

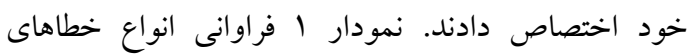

وجود اينكه ميزان وقوع اين گونه از خطاها مىتواند به عنوان يكى از شاخصهاى حفظ ايمنى بيماران به كار رود تاكنون ميزان بروز اين دسته از خطاها در ايران بسيار كم مورد

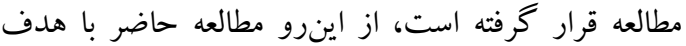

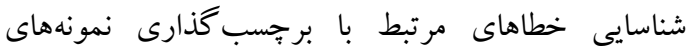
ياتولوزى جراحى ارسال شده از بخشهاى مختلف بيمارستانهاى آموزشى دانشكاه علوم يزشكى قزوين مىباشد.

مواد و روشها مطالعه حاضر يك بيزوهش توصيفى تحليلى است كه به

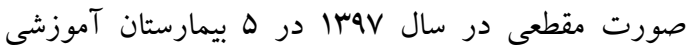

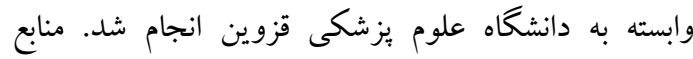

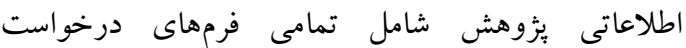
پِاتولوزى بود كه در اتاقهاى عمل بيمارستانهاى شهر

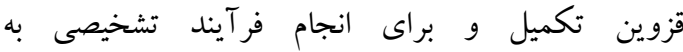
آزمايشگاههاى پاتولوزى بيمارستانها ارسال شده بود. در

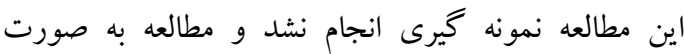
سرشمارى در مدت يكك ماهه (مرداد ماه) انجام شد. در اين مطالعه خطاهاى مربوط به نمونههاى بِاتولوزى از اختلاف موجود بين اطلاعات ثبتشده در فرم درخواست پاتولوزى و اطلاعات موجود در برجسب نمونه ارسال شده به آزمايشكاه شناسايى شدند. براى اين منظور بعد از اخذ إند

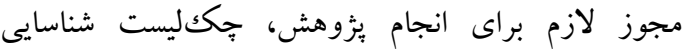

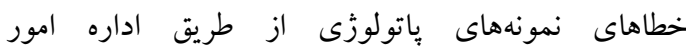

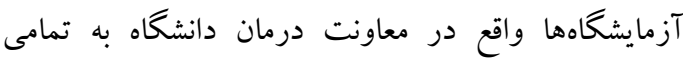
واحدهاى باتولوزى موجود در بيمارستانهاى وابسته به

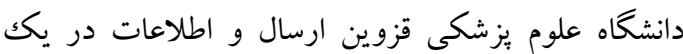

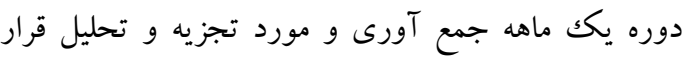

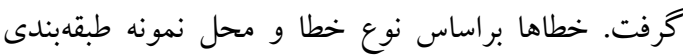

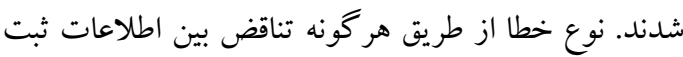
شده در فرم درخواست و بر جسب نمونه شناسايى شدند؛ مثلا خطا نمونه فاقد برجسب، كه به نمونههاى بدون برجسب 
بخش ياتولوزى بيمارستانهاى مورد مطالعه ارسال شده است. جدول ا فراوانى بخشهاى نمونهبردارى شده را نشان

شناسايى شده مربوط به برجسبهاى نمونهاى جراحى را نشان مىدهد. نتايج مطالعه همجينين نشان داد كه بيشترين نمونهها از بخشهاى جراحى (F/F در دصد)، بخش كوش و

حلق و بينى (I/ / درصد) و بخش اطفال (V/V درصد) به

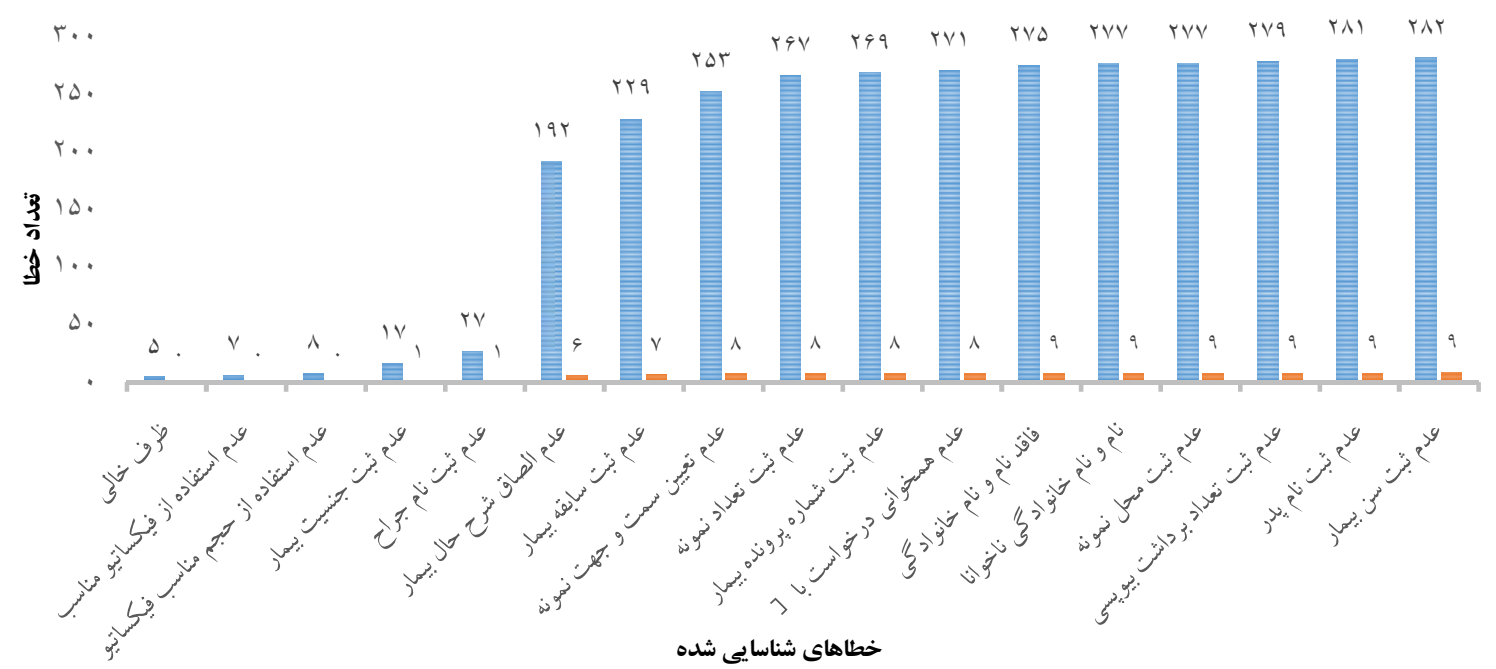

نمو دار ا. فراوانى انواع خطاهاى شناسايى شده مرتبط با برجسبهاى نمونههاى جراحى

جدول ا. توزيع فراوانى محل نمونهبردارى

\begin{tabular}{|c|c|c|}
\hline درصد & تعداد & محل نمونهبردارى \\
\hline$G Y / F$ & VrF & جراحى \\
\hline $14 / 1$ & IOF & كوش و حلق و بينى \\
\hline$V / V$ & 9. & اطفال \\
\hline $9 / 1$ & VY & داخلى \\
\hline $4 / 9$ & $\Delta \wedge$ & آندوسكويى \\
\hline $1 / 9$ & rr & اورولوزى \\
\hline $1 / 4$ & If & اتاق عمل سريايى \\
\hline 1 & ir & قلب \\
\hline.$/ 9$ & 1. & ان اى سى يو \\
\hline$\cdot / r$ & f & سى سى يو \\
\hline$\cdot / \mu$ & f & اى سى يو \\
\hline$\cdot / r$ & r & درمانكاه \\
\hline $1 \cdots$ & 1194 & كل \\
\hline
\end{tabular}


مرحله قبل از تجزيه و تحليل تمركز داشت جون به ندرت مورد توجه و بررسى قرار گرفته است و با توجه به كمبود تحرد نظارت موجود در اين مرحله و تفاوتهايى كه در شيوه كار

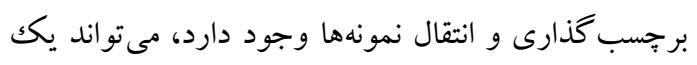
منبع با ارزش و مهمى در خصوص مخاطرات و صدمات

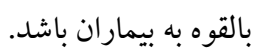

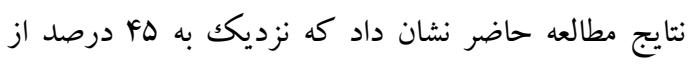

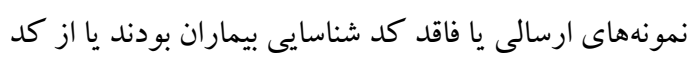
شناسايى اشتباه براى نمونه ارسالى استفاده شده است. نتايج

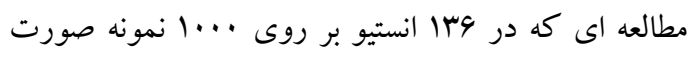

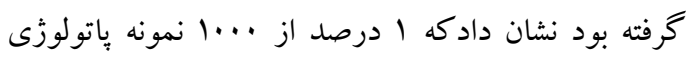

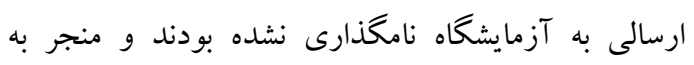
آسيب به بيماران شده بودند(Y) آرسائ همجنين در مطالعات مشابهى كه در يكك انستيتو صورت گرفته بود نتايج آنها

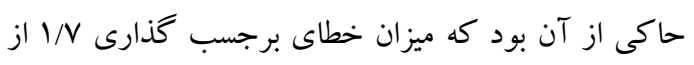

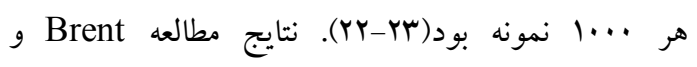

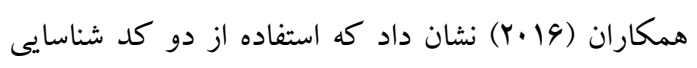
بيماران به طور همزمان در يكك دوره شش ماهه نزديك به

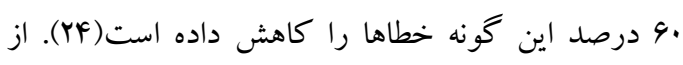
اينرو به نظر مىرسد استفاده همزمان از دو كد شناسايى براى بيماران به طور همزمان مىتواند باعث كاهش قابل

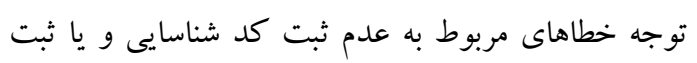
نادرست كدشناسايى بيماران گردد.

نتايج مطالعه نشان داد كه ردگيرى تعداد نمونهاى جراحى

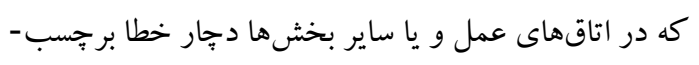

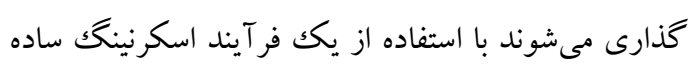

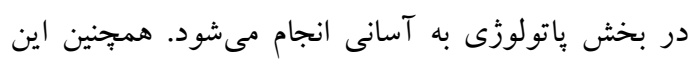

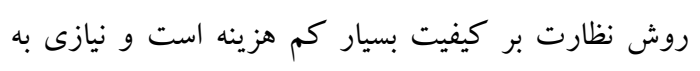

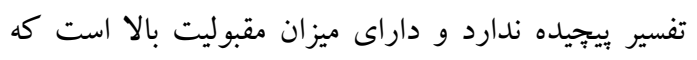
باعث مىشود ايمنى بيمار بطور موثرترى در كك شود.
نتايج مطالعه همجنين نشان داد كه بيشترين نمونههاى ارسالى

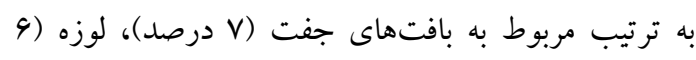
درصد) و آندومتر (F) درصد) بود.

مطالعه حاضر با هدف شناسايى خطاهاى مربوط به نمونههاى

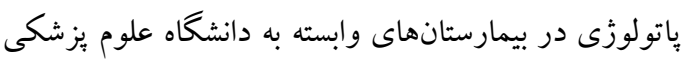
قزوين انجام شد. نتايج اين مطالعه نشان داد كه بروز خطاهاى مربوط به برجسب گذزارى در بيمارستانهاى مورد إن

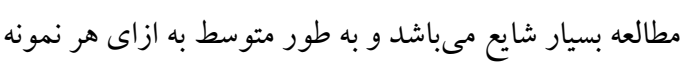

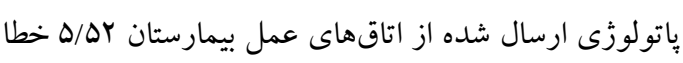
رخ مىدهد كه اين تعداد خطا، مخاطرات معنىدارى را براى ايمنى بيماران مطرح مى كند. Makary و هم هماران (Y..V)

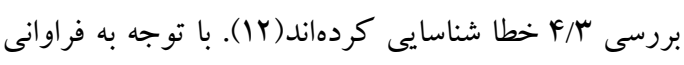
بالايى اين خطاها و همجينين امكان يذيرى اندازه گيرى آنها،

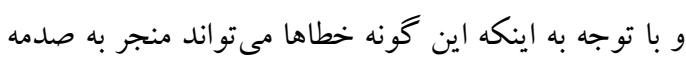

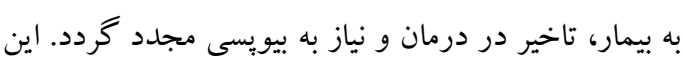

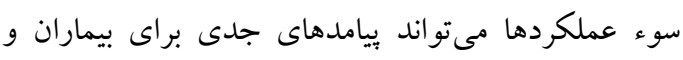

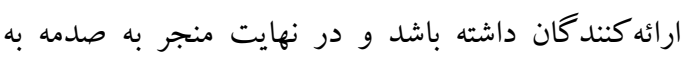
بيماران، افزايش هزينهاى بيمارستان و بى اعتمادى جامعه

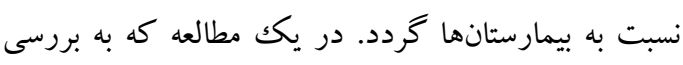
تاثير بالينى خطاها در تشخيص نمونههاى جراحى برداخته

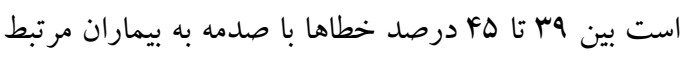
بود(19). خطاهاى مربوط به نمونهاى جراحى معمولاً در سه مرحله رخ مىدهند: مرحله قبل از تجزيه و تحليل (انقال

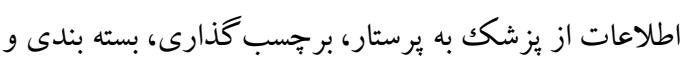

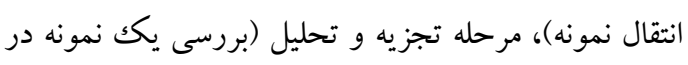

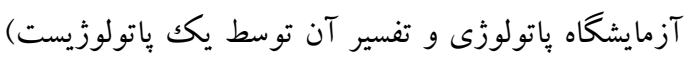

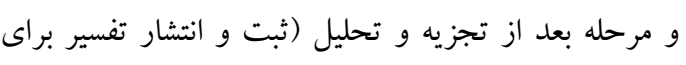
يزشك). دو مرحله آخر به خوبى در مطالعات كذشته مورد

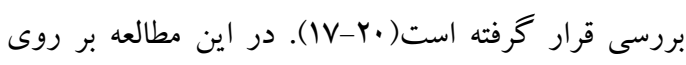

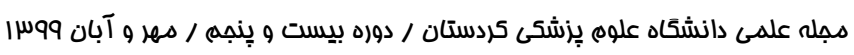




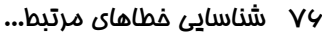

قبيل خلاصه سازى يروتكلها، سيستم ارزشيابى رويدادهاى ناگوار از قبيل برنامههاى جامع ايمنى بيمار و بهبود فر آيند انتقال اطلاعات حياتى و فرآيندهاى استفاده شده در بر بر

$$
\text { ارزشيابى اشتباهات موثر هستند. }
$$

\section{تشكر و قدردانى}

اين يزٔوهش در دانشگاه علوم بزشكى قزوين با كد طرح IR.QUMS.REC.1395.10 انجام شده است. بدينوسيله از همه همكاران محترم شاغل در واحد آزمايشگاه بيمارستانهاى آموزشى شهر قزوين كه تيم يُوهشى را در انجام اين يُوهش يارى رساندند كمال تشكر را داريم.
نتايج مطالعه ما نشان داد كه متوسط ميزان خطاهاى شناسايى مرتط نمونه ها نزديكك سم/N درصد بود. در مطالعهى Fabbretti و همكاران (111) كه بر روى Y991 نمونه صورت گرفته بود ميزان خطاى شناسايى نمونه ياتولوزى در بس نمونه (T/T) درصد) مشاهده شد(F). (F). به طور كلى با توجه به اينكه تعريف، ابزار و روششناسى استانداردى در خصوص شناسايى و طبقه بندى انواع خطاهاى مربوط به برجسبكذارى وجود ندارد بر آورد دقيق و مقايسه شيوع اين خطاها در موسسات مختلف و همجنين شناسايى انواع خطاها كه بسيار هم شايع هستند مشكل است. نتيجه تيرى از آنجايى كه خطاهاى مربوط به نمونهاى باتولوزى يك منبع نادر اما بسيار مهم در خطاهاى بزشكى مىباشند و مىتوانند ايمنى بيماران را به خطر بيندازند، از اينرو اتخاذ تدابيرى همجون طراحى فرمهايى در تمامى بخشها جهت انجام و تحويل نمونه بيوبسى به واحد آزمايشگاه و جِك مجدد آن توسط تيم ارائه دهنده خدمات يا برستار مربوطه، استفاده از فناورى باركد در ظرفهاى نمونه، حذف كاغذى فرم درخواست انجام پِاتولوزى، استفاده از radio frequency ( تكنولوزى تراشه فر كانس راديويى (chip technology مجدد و بهبود ارتباطات در اتاقهاى عمل مىتواند در كاهش ميزان خطاهاى برجسب گذارى نمونهاى جراحى بكاهد. با توجه به اينكه هدف اصلى ايمنى كميسيون مشتركى اعتبار بخشى موسسات بهداشتى درمانى - نياز به برجّب گذارى نمونهاى جراحى با حداقل دو شناسه تعيين كننده هويت بيمار و يكك مرحله تاييد قبل از عمل در حضور يزشك- مىباشد؛ اجراى آن توسط تمامى بخشهاى بيمارستان مىتواند در فرآيند استانداردسازى يروتكل برجسب كذارى كمكك كننده باشد. علاوه بر اين تلاشهاى اخير براى بهبود ارتباطات در اتاقهاى عمل از

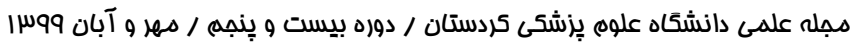


1. Vlayen A, Schrooten W, Wami W, Aerts M, Barrado LG, Claes N, et al. Variability of patient safety culture in Belgian acute hospitals. J Patient Saf. 2015;11(2):110-21.

2. Ammouri AA, Tailakh AK, Muliira JK, Geethakrishnan R, Al Kindi SN. Patient safety culture among nurses. Int Nurs Rev. 2015;62(1):102-10.

3. Fan CJ, Pawlik TM, Daniels T, Vernon N, Banks K, Westby P, et al. Association of safety culture with surgical site infection outcomes. J Am Coll Surg. 2016;222(2):122-8.

4. Halverson AL, Casey JT, Andersson J, Anderson K, Park C, Rademaker AW, et al. Communication failure in the operating room. Surgery. 2011;149(3):305-10.

5. Mills P, Neily J, Dunn E. Teamwork and communication in surgical teams: implications for patient safety. J Am Coll Surg. 2008;206(1):107-12.

6. Brock D, Abu-Rish E, Chiu C-R, Hammer D, Wilson S, Vorvick L, et al. Republished: interprofessional education in team communication: working together to improve patient safety. Postgrad Med J. 2013;89(1057):642-51.

7. Makary MA, Sexton JB, Freischlag JA, Holzmueller CG, Millman EA, Rowen L, et al. Operating room teamwork among physicians and nurses: teamwork in the eye of the beholder. J Am Coll Surg. 2006;202(5):746-52.

8. Sirota RL. A framework for error in anatomic pathology. AJSP Rev Reports. 2009;14(2):53-6.

9. Robert L. Schmidt, Bonnie L. Messinger, Lester J. Layfield, Internal Labeling Errors in a Surgical Pathology Department: A Root Cause Analysis, Laboratory Medicine. 2013; 44(2): 176-185.

10. Layfield LJ, Anderson GM. Specimen labeling errors in surgical pathology: an 18-month experience. Am J Clin Pathol. 2010;134(3):466-70.

11. Laboratory services: 2014 national patient safety goals. The Joint Commission Web site. http://www.jointcommission.org/standards_information/ npsgs.aspx. Accessed October 10, 2014.

12. Makary MA, Epstein J, Pronovost PJ, Millman EA, Hartmann EC, Freischlag JA.

Surgical specimen identification errors: a new measure of quality in surgical care. Surgery. 2007;141(4):450-5.

13. Zarbo RJ, Tuthill JM, D'Angelo R, Varney R, Mahar B, Neuman C, Ormsby A. The

Henry Ford production system: reduction of surgical pathology in-process misidentification defects by bar codespecified work process standardization. Am J Clin Pathol.

2009;131(4):468-477.

14.Fabbretti G. The role of 2D bar code and electronic cross-matching in the reduction of misidentification errors in a pathology laboratory: a safety system assisted by the use of information technology. Pathologica. 2011;103(6):313-317.

15.Morrison AP, Tanasijevic MJ, Goonan EM, Lobo MM, Bates MM, Lipsitz SR, et al. Reduction in specimen labeling errors after implementation of a positive patient identification system in phlebotomy. Am J Clin Pathol. 2010;133(6):870-7.

16. Raab SS, Grzybicki DM, Janosky JE, Zarbo RJ, Meier FA, Jensen C, et al. Clinical impact and frequency of anatomic pathology errors in cancer diagnoses. Cancer. 2005;104(10):2205-13.

17.Anonymous. Specimen labeling QI project cuts error rate. Healthcare Benchmarks Qual Improv. 2006;13:137-138.

18. Raab SS, Nakhleh RE, Ruby SG. Patient safety in anatomic pathology: measuring discrepancy frequencies and causes. Arch Pathol Lab Med. 2005;129(4):459-66. 
19.Quillen K, Murphy K. Quality improvement to decrease specimen mislabeling in transfusion medicine. Arch Pathol Lab Med. 2006; 130(8): 1196-1198.

20.Wagar EA, Stankovic AK, Raab S, Nakhleh RE, Walsh MK. Specimen labeling errors: a Q-Probes analysis of 147 clinical laboratories. Arch Path Lab Med. 2008;132(10):1617-1622.

21.Nakhleh RE, Idowu MO, Souers RJ, Meier FA, Bekeris LG. Mislabeling of cases, specimens, blocks, and slides: a College of American Pathologists study of136 institutions. Arch Pathol Lab Med. 2011;135(8):969-974.

22.Schmidt RL, Messinger BL, Layfield LJ. Internal labeling errors in a surgical pathology department: a root cause analysis. Lab Med. 2013;44(2):176-185.

23.Smith ML, Raab SS. Assessment of latent factors contributing to error: addressing surgical pathology error wisely. Arch Pathol Lab Med. 2011;135(11): 1436-1440.

24. Brent MAZ. OR specimen labeling. AORN J. 2016;103(2):164-76. 